\title{
DENTAL CONDITIONS WITH ASSOCIATED SIGNS OF NUTRITIONAL DEFICIENCIES IN NEWFOUNDLAND CHILDREN
}

\author{
BY \\ HELEN MELLANBY \\ From the Nutrition Buildings, National Institute for Medical Research, London, N.W.7
}

(RECEIVED FOR PUBLICATION NOVEMBER 6, 1951)

In undertaking this survey of Newfoundland children the primary concern was the incidence of dental disease, but an opportunity was taken of noting any signs suggestive of nutritional deficiencies which were observed during the examination of the individuals. The time of the visit (May-July, 1948) was chosen because it followed soon after the Newfoundland Government's latest measure designed to improve the standard of nutrition, namely that of adding $0.5 \%$ of bone meal to all flour before importation. This reinforcing of a staple article of diet was done to raise the low calcium intake, and, since it provides small amounts of fluorine as well as extra calcium, it might be expected to have some beneficial effect on the children's teeth. It was hoped that a subsequent survey might be made after the lapse of some years to estimate any alteration in the dental condition of the child population, especially of their caries susceptibility. For this latter reason the general results only will be given in this paper, leaving a more detailed assessment of the findings until such time as a future comparison may become available.

Newfoundland, at the mouth of the Gulf of St. Lawrence, has an area of 42,000 square miles and thus is a little smaller than England. At the last census in 1948 the population was 340,000 , of which about one half was resident in the Avalon Peninsula. St. Johns, the capital, is the only town of any size $(56,000)$ after which come the paper-mill company towns of Corner Brook and Grand Falls, having 10,500 and 7,300 inhabitants respectively, including their satellite settlements. The majority of the people live in small coastal fishing communities, of 200 to 800 individuals, many of which are relatively isolated for a large part of the year. The local name for these is "outports". On the Avalon Peninsula the outports have fairly good road communications, but others, on the south and north coasts particularly, have none except by sleigh in winter, while sea transport is often restricted by bad weather. The single track, narrow gauge railway provides an additional link between the main population centres as it traverses the island from St. Johns in the south-east to Port aux Basques in the south-west. A few roads have been built from some of the northern and western outports to the nearest railhead.

For many years it has been known that nutritional diseases such as beri-beri have been endemic in this part of the world (Little, 1912; Appleton, 1921; Aykroyd, 1930), and much has been written about the combination of circumstances which has in the past contributed to this state of affairs. The islanders have to contend with somewhat unfavourable climatic conditions which permit of only a short season for growing vegetable and livestock crops. In many places the soil is so scanty that potato patches are often only a few square yards in area, lying between rocks. Previously, almost the only occupation for the men was fishing, the start of which coincided with planting time, so that the 'gardens' were largely left to the women. Following a poor fishing season there was extreme poverty and the diets of the people, apart from the potatoes, cabbage and turnips grown in their own gardens, became restricted to cheap foodstuffs which could be stored for months, such as white flour $(70 \%$ extraction), sugar, molasses, tea and margarine, to which salted fish (almost exclusively cod) and salted pork were added. Wild fruits, such as cranberries and bakeapples, were ga.hered and preserved for use in the winter. Very little use was made of dairy products owing to their scarcity, due again to the difficulty and expense of stallfeeding for many months of the year. Recently a number of important alternative occupations to fishing has grown up and there has been a period of comparative prosperity, but even so, this has not remedied the lack of dairy products very much. Livestock observed during my visits to the outports consisted of a few goats, an occasional cow, a few nondescript hens and some sheep. Many families still use no milk at all, apart from 
a little of the much-diluted tinned product in their tea.

During the last eight years several groups of workers have visited the country to make sample surveys of the population for signs and symptoms of deficiency diseases and to assess the average dietary standards of the islanders (McDevitt, Dove, Dove, and Wright, 1944; Adamson* et al., 1945; Metcoff et al., 1945; Cuthbertson, 1947; Scobie, Burke and Stuart, 1949; Aykroyd* et al., 1949). Though none of these surveys was specifically concerned with teeth, most workers commented on the great prevalence of dental decay and gingival disease. Indeed Aykroyd et al. (1949) consider that these have actually increased between 1944 and 1948.

\section{Clinical Material}

In planning this survey an attempt was made to sample all types of communities, but in order to obtain adequate numbers within the time limit of seven weeks, it was necessary to include the larger population centres such as the capital, St. Johns $(56,000)$, the mining district of Bell Island $(8,000)$ and the two paper-mill towns of Grand Falls $(7,300)$ and Corner Brook $(10,500)$ with their surrounding settlements (see map). Besides these larger aggregations of the population, three groups of outports were visited: (1) those on the Avalon Peninsula with roads connecting with St. Johns; (2) those on the Burin Peninsula having road communications with each other, but not at that time with the rest of the Island; (3) those of the south-west coast and Fortune Bay area which are isolated, except by boat, for some seven months of the year. It will be appreciated that the maintenance of an adequate health service to areas such as the Fortune Bay region presents special problems. In the case of dental treatment, the service was limited to extractions.

In this survey the children in all the larger centres of population were inspected at their schools, the

* Adamson, J. D., Jolliffe, N., Kruse, H. D., Lowry, O. H., Moore, P. E., Platt, B. S., Sebrell, W. H., Tice, J. W., Tisdall, F. F., Jolliffe, N., Lowry, O. H., Moore, P. E., Sebrell, W. H., Shank, Jolliffe, T., Tisdall, F. F., Wiider, R. M. and Zamecnik, P. C. (1949); Metcoff, J., Goldsmith, G. A., McQueeney, A. J., Dove, R. F., McDevitt, E., Dove, M. A. and Stare, F. J. (1945). 
absence of enamel over small areas were classed together as 'gross hypoplasia' which is the type usually described in textbooks. While every effort was made to keep this standard for hypoplasia comparable from day to day by referring to sets of graded shed and extracted teeth, it is felt that the examination of large groups of deciduous and permanent teeth, often in the same day, would tend to lower the standards for deciduous teeth, since these are on the whole so much smoother than their permanent successors. An average hypoplasia figure (A.H.F.) for groups of teeth was calculated by allotting one point to all teeth graded $M-h y_{1}$, two points to $M-h y_{2}$ teeth, three points to $M-h y_{3}$ teeth and dividing the sum of the points by the total number of teeth examined for structure.

The incidence of caries was estimated as carefully as possible, each lesion being recorded as 1,2 or 3 according to the criteria adopted in previous surveys by May Mellanby and her colleagues (Mellanby and Coumoulos, 1944 and 1946; Mellanby and Mellanby, 1948). An average caries figure (A.C.F.) was worked out for groups of teeth on the same lines as the average hypoplasia figure. All missing deciduous canines and molars in the 5-year-olds were considered to have been extracted for caries, and were given a caries score of three. Missing incisors were considered to have been naturally shed, except where a reliable history of extraction was obtained from the mother. In the 14-year group all missing incisors and first molars were counted as extracted and were given a $C_{3}$ caries rating. A few absent canines, premolars and second molars were obviously unerupted and these were not counted as carious.

Gingivitis, Cheilosis and Other Signs Suggesting Nutritional Deficiency. Notes were made of any 5- or 14-year-old child showing gingivitis which was roughly classified as $0,1,2$ or 3 depending on the extent of the condition and on the amount of hyperaemia and swelling of the interdigital papillae in each child (see Mellanby and Mellanby (1951) for details). Signs visible to the naked eye suggesting riboflavine, nicotinic acid or vitamin A deficiency were also recorded, but it must be emphasized that such signs were restricted to their appearance on the face and in the mouth of the child examined, and their significance is limited by the author's lack of previous experience in the clinical manifestations of the vitamin B deficiencies. The principal signs attributed to deficiency of one or more members of the vitamin B complex looked for were those mentioned by Sydenstricker (1941a and $b$ ) and illustrated in the Medical Survey of Nutrition in Newfoundland by Adamson et al. (1945) and in the recent re-survey of the same places by Aykroyd et al. (1949), namely those associated with ariboflavinosis such as cheilosis, angular fissuring of the mouth, magenta tongue and blepharitis and those associated with nicotinic acid insufficiency, giving tongue changes featuring hypertrophied or atrophied tongue papillae, fissuring, or oedema as evidenced by tooth impressions along the tongue margins. It was more difficult to be dogmatic about the skin and hair changes probably related to vitamin A deficiency, as so many of the children in the outports had obviously unbrushed hair, and the rather rough skin on their faces might be due, at least in part, to climatic conditions. Eye changes attributable to vitamin A deficiency were not observed in these young age groups.

\section{Results}

Caries in 5- and 14-year-old Groups. The general results for the prevalence of tooth decay in the Island, according to the locality, are given for the principal age groups of 5 and 14 years in Tables 1

TABLE 1

Caries in S-year-old Newfoundland ChILdRen in 1948

\begin{tabular}{|c|c|c|c|c|c|c|c|c|c|c|}
\hline \multicolumn{4}{|c|}{ Locality } & \multirow{2}{*}{$\frac{\text { Principal Occupations }}{\text { Various urban }}$} & \multirow{2}{*}{$\begin{array}{c}\begin{array}{c}\text { No. } \\
\text { Children } \\
\text { Examined }\end{array} \\
281\end{array}$} & \multirow{2}{*}{$\begin{array}{c}\begin{array}{c}\text { Percentage } \\
\text { Mouths } \\
\text { Caries-free }\end{array} \\
5 \cdot 7\end{array}$} & \multirow{2}{*}{$\begin{array}{c}\frac{\text { Total No. }}{\text { Teeth }} \\
5,410\end{array}$} & \multirow{2}{*}{$\begin{array}{c}\begin{array}{c}\text { Percentage } \\
\text { Teeth } \\
\text { Carious }\end{array} \\
38 \cdot 5\end{array}$} & \multirow{2}{*}{$\frac{+ \text { A.C.F. }}{0.82}$} & \multirow{2}{*}{$\frac{\begin{array}{l}\text { D.M.F. } \pm \\
\text { (per child) }\end{array}}{7 \cdot 4}$} \\
\hline St. Johns & . & .. & . & & & & & & & \\
\hline Bell Island & $\cdots$ & $\cdots$ & . & Iron ore mining & 66 & $10 \cdot 6$ & 1,260 & $31 \cdot 7$ & $0 \cdot 68$ & $6 \cdot 0$ \\
\hline \multicolumn{4}{|c|}{$\begin{array}{l}\text { Inland towns: } \\
\text { Corner Brook, Gander, } \\
\text { Grand Falls, Windsor }\end{array}$} & $\begin{array}{l}\text { Lumbering, paper } \\
\text { manufacture, airport } \\
\text { personnel }\end{array}$ & 222 & $2 \cdot 3$ & 4,266 & $42 \cdot 5$ & 0.94 & $8 \cdot 2$ \\
\hline \multicolumn{4}{|c|}{$\begin{array}{l}\text { Outports: } \\
\text { (1) Avalon Peninsula }\end{array}$} & $\begin{array}{l}\text { Fishing, fish processing, } \\
\text { small amount of manu- } \\
\text { facturing }\end{array}$ & 70 & $10 \cdot 0$ & 1,362 & $40 \cdot 2$ & $0 \cdot 83$ & $7 \cdot 8$ \\
\hline \multicolumn{4}{|c|}{$\begin{array}{l}\text { (2) Burin Peninsula (ex- } \\
\text { cluding St. Lawrence) }\end{array}$} & $\begin{array}{l}\text { Fishing and fish } \\
\text { processing }\end{array}$ & 67 & $10 \cdot 5$ & 1,299 & $35 \cdot 8$ & $0 \cdot 72$ & $6 \cdot 9$ \\
\hline \multirow{2}{*}{\multicolumn{3}{|c|}{$\begin{array}{l}\text { St. Lawrence* } \\
\text { (3) S.W. coast and } \\
\text { Fortune Bay . }\end{array}$}} & .. & Fluorspar mining & 17 & $70 \cdot 5$ & 340 & $6 \cdot 2$ & $0 \cdot 12$ & $1 \cdot 2$ \\
\hline & & & & $\begin{array}{l}\text { Lumbering at St. } \\
\text { Albans, fishing and } \\
\text { some fish processing }\end{array}$ & 81 & $4 \cdot 9$ & 1,593 & $40 \cdot 7$ & $0 \cdot 83$ & $8 \cdot 0$ \\
\hline Totals & $\cdots$ & . & $\cdots$ & & 804 & $7 \cdot 2$ & 15,530 & $38 \cdot 5$ & 0.82 & $7 \cdot 4$ \\
\hline
\end{tabular}

- Area of endemic fluorosis. $\quad+$ Average caries figure $=$ total caries figure 
TABLE 2A

- Caries in 14-year-old Newfoundland Children in 1948

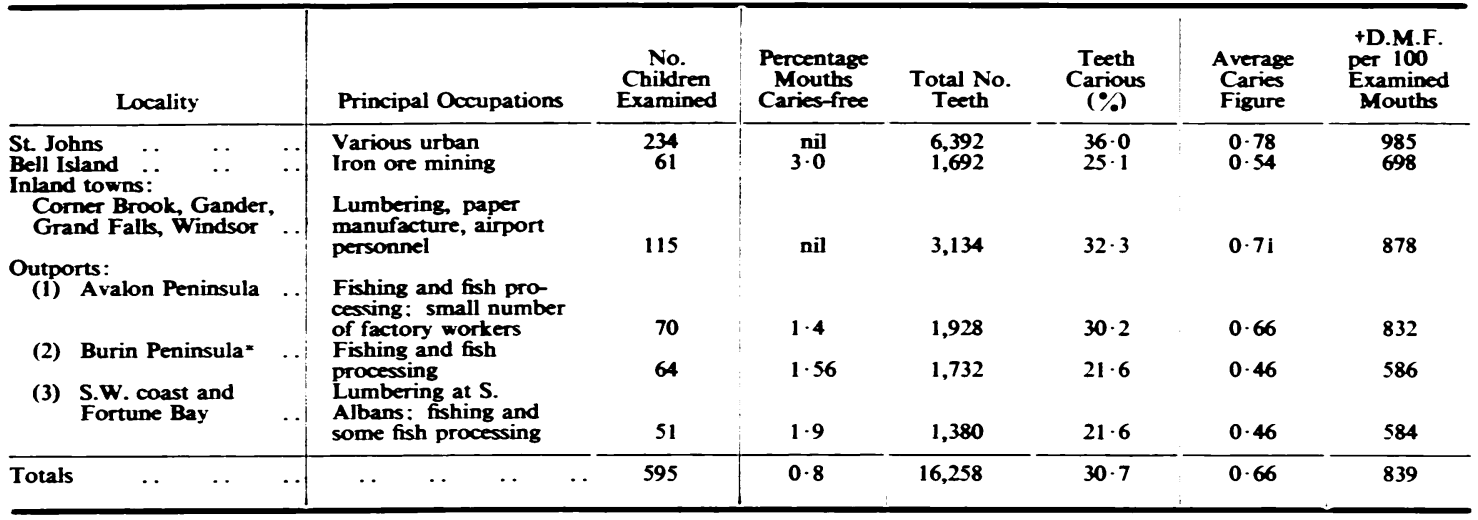

* There were four individuals only in this age group resident in the fluorosis area of St. Lawrence. + D.M.F. = decayed, missing, filled.

and 2. A glance at these is sufficient to show that dental caries is very common. In the 5-year-old age group only $7 \cdot 2 \%$ of children had no decayed teeth, while $38.5 \%$ of all deciduous teeth at this age were already attacked. This is equivalent to a ' decayed, missing, filled' rate (D.M.F.) per child of $7 \cdot 4^{*}$. There was some slight variation in different geographical areas, the Bell Island children and those living in the Avalon and Burin Peninsula outports having rather less decay, while young children of St. Lawrence (an endemic fluorosis area) had a low incidence. For comparison with these Newfoundland results some figures are given in Table 2B for deciduous teeth in other groups of children.

Turning to the older group, children aged 14 showed less than $1 \%$ of mouths with no decay, while the percentage of permanent teeth attacked was $30 \cdot 7$, giving a D.M.F. of $8 \cdot 39$ per child. There was again some variation in different localities, Bell Island children and those of the Burin Peninsula and south-west coast area having less decay of their permanent teeth than those in the Avalon Peninsula outports, St. Johns or the paper-mill towns. The second part of Table 2B gives comparative results for other groups of children of approximately the same age. Many more comparative figures could be given, but from Tables $1,2 \mathrm{~A}$ and $2 \mathrm{~B}$ it is evident that dental caries is almost universal in Newfoundland and the average number of teeth attacked is high in comparison with the U.S.A. or London, where the disease is considered all too common.

More detailed results for the various types of

* In assessing the D.M.F. for deciduous teeth, missing incisors were assumed to have been naturally shed, and were therefore not counted as 'missing due to extraction' except where a definite history was obtained. teeth will be given elsewhere, but at 5 years of age $46 \%$ of the deciduous upper central incisors and $71 \%$ and $76 \%$ of the lower first and second deciduous molars were already decayed. In the permanent teeth of the 14-year-olds, $31 \%$ of the upper central incisors, $79 \%$ of the upper 6 -year-old molars, and $88 \%$ of the lower 6-year-old molars were carious.

Structure in 5- and 14-year-old Groups. In Table 3 will be found a synopsis of the results of examining both deciduous and the permanent teeth for surface structure (or M-type hypoplasia). From this it will be seen that among the deciduous teeth, only $27.8 \%$ were considered normal, the remaining $72.2 \%$ having some degree of surface roughness and giving an average hypoplasia figure of $1 \cdot 06$. The teeth of the upper jaw were definitely rougher than those of the lower, one reason for this probably being the tartar deposits commonly found on the upper molars, especially where little or no oral hygiene is practised. In fact $10 \%$ of the upper first molars and $25 \%$ of the upper second molars had readily visible tartar deposits.

Comparative results for tooth structure in London 5-year-olds showed $47 \%$ of all deciduous teeth in 1947 to have no M-type hypoplasia (Mellanby and Mellanby, 1948), while the results for a group of German children gave $50 \%$ with no M-hypoplasia (Mellanby, H., 1949). The average hypoplasia figure for the Newfoundland group was 1.06 , for the London group 0.67 and for the German group 0.66. The deciduous teeth of the Newfoundland children may therefore be said to be of poorer structure than either of the other two groups.

In the permanent teeth (Table 3) only 8.7\% could be said to be of smooth structure, while 
some $91 \cdot 3 \%$ had some degree of M-type hypoplasia. Again the upper jaw teeth are apparently of worse structure than the lower teeth, but considerable deposits of tartar on the upper first and sometimes the second molars, were common. Many of the -6-year-old molars' were so carious at this age, that insufficient crown surface remained for structure estimation.

In comparing the structure of the permanent teeth, of which only $8.7 \%$ were found to have no M-hypoplasia, with a group of London 14-year-olds (Mellanby and Mellanby, in press) some 23.6\% of these latter in 1947 had smooth teeth, the average hypoplasia figure being 0.92 compared with $1 \cdot 38$ for the Newfoundland children. Therefore the permanent teeth of Newfoundland children also may be considered to be of poor average structure as assessed by this method.

Dental Caries and Tooth Structure in St. Lawrence Outport. In striking contrast to the mouths full of decayed teeth seen in all other parts of the island which were visited, the children of the outport called St. Lawrence, with a population of 800 according to the 1948 census, showed a high proportion of caries-free individuals. This settlement turned out to be an area of endemic fluorosis, where mottling of the permanent teeth was common. Unfortunately this fact was only discovered on arrival, so that the most had to be made of a half day's visit, which was all the time that the travelling schedule permitted. The water supply to one of the fluospar mines, for which accurate analyses

TABue 2B

Dental Cartes in Groups of Chimden from Varous Parts of the World

\begin{tabular}{|c|c|c|c|c|c|c|c|c|}
\hline Place & Author & $\begin{array}{l}\text { Date of } \\
\text { Survey }\end{array}$ & $\begin{array}{l}\text { No. of } \\
\text { Children } \\
\text { Examined }\end{array}$ & $\begin{array}{l}\text { Age } \\
\text { Group }\end{array}$ & $\begin{array}{c}\text { Per- } \\
\text { centage } \\
\text { of In- } \\
\text { dividuals } \\
\text { Caries-free }\end{array}$ & $\begin{array}{c}\text { Per- } \\
\text { centage } \\
\text { of Teeth } \\
\text { Carious } \\
\text { (D.M.F.* } \\
\text { per 100 } \\
\text { Teeth) }\end{array}$ & $\begin{array}{l}\text { Average } \\
\text { No. of } \\
\text { Carious } \\
\text { Teeth } \\
\text { per Child } \\
\text { (D.M.F. } \\
\text { per Child) }\end{array}$ & Comments \\
\hline London, England & $\begin{array}{l}\text { Mellanby, M. and } \\
\text { Mellanby, H. (1948) }\end{array}$ & 1947 & 1,590 & 5 & $28 \cdot 1$ & $20 \cdot 3$ & $3 \cdot 94$ & $\begin{array}{l}\text { Children from State } \\
\text { schools }\end{array}$ \\
\hline $\begin{array}{l}\text { Wuppertal, } \\
\text { Germany }\end{array}$ & Mellanby, H. (1949) & 1948 & 563 & 5 & $28 \cdot 4$ & $14 \cdot 2$ & $2 \cdot 79$ & $\begin{array}{l}\text { Children from State } \\
\text { and private kinder- } \\
\text { gartens }\end{array}$ \\
\hline London, England & $\begin{array}{l}\text { Mellanby, H. and } \\
\text { Mellanby, M. (1950) }\end{array}$ & 1949 & 692 & 5 & $14 \cdot 9$ & $26 \cdot 7$ & $4 \cdot 66$ & $\begin{array}{l}\text { Children from State } \\
\text { schools }\end{array}$ \\
\hline Hagerstown, U.S.A. & $\begin{array}{l}\text { Knutson, Klein and } \\
\text { Palmer (1940) }\end{array}$ & 1938 & 327 & 6 & $\begin{array}{l}\text { not } \\
\text { given }\end{array}$ & $\begin{array}{c}\text { not } \\
\text { given }\end{array}$ & $5 \cdot 16$ & $\begin{array}{l}\text { Grade-school- } \\
\text { children }\end{array}$ \\
\hline $\begin{array}{l}\text { Blaker and Fet, } \\
\text { Norway }\end{array}$ & Toverud (1949) & $\begin{array}{l}1939 \\
1947\end{array}$ & & $\begin{array}{l}4-5 \\
4-5\end{array}$ & $\begin{array}{r}1 \cdot 0 \\
28 \cdot 0\end{array}$ & $\begin{array}{l}47 \\
21\end{array}$ & $\overline{-}$ & $\begin{array}{l}\text { Rural areas } \\
\text { Rural areas }\end{array}$ \\
\hline $\begin{array}{l}\text { U.S.A. (American } \\
\text { Indians in Reserves) }\end{array}$ & $\begin{array}{l}\text { Klein and Palmer } \\
(1937)\end{array}$ & $1929 / 33$ & 1,300 & $14 \& 15$ & 23 & $11 \cdot 1$ & $3 \cdot 12$ & $\begin{array}{l}\text { Children distributed } \\
\text { between } 76 \text { Reserves } \\
\text { in } 16 \text { States }\end{array}$ \\
\hline $\begin{array}{l}\text { Isle of Lewis, } \\
\text { Scotland }\end{array}$ & King (1940) & 1937 & 185 & $13-15$ & $30 \cdot 8$ & $8 \cdot 5$ & $2 \cdot 2$ & $\begin{array}{l}\text { Rural fishing com- } \\
\text { munities }\end{array}$ \\
\hline $\begin{array}{l}\text { Hagerstown, } \\
\text { Maryland, U.S.A. }\end{array}$ & $\begin{array}{l}\text { Klein, Paimer and } \\
\text { Knutson (1938) }\end{array}$ & 1937 & 364 & 14 & $4 \cdot 6$ & $19 \cdot 2$ & $5 \cdot 2$ & $\begin{array}{l}\text { Typical east U.S.A. } \\
\text { small town }\end{array}$ \\
\hline Chicago, U.S.A. & $\begin{array}{l}\text { Dean, Jay, Arnold } \\
\text { and Elvove (1941) }\end{array}$ & 1939 & 2,832 & $12-14$ & $\begin{array}{c}14 \cdot 4 \\
\text { (average) }\end{array}$ & - & $\begin{array}{c}4 \cdot 73 \\
\text { (average) }\end{array}$ & $\begin{array}{l}\text { Average of } 8 \text { separate } \\
\text { communities }\end{array}$ \\
\hline $\begin{array}{l}\text { Italy (four northern } \\
\text { cities) }\end{array}$ & $\begin{array}{l}\text { Schour and Massler } \\
(1947)\end{array}$ & 1945 & 475 & $11-15$ & $53 \cdot 4$ & - & $1 \cdot 05$ & $\begin{array}{l}\text { Deciduous and per- } \\
\text { manent teeth included }\end{array}$ \\
\hline Trinidad & $\begin{array}{l}\text { King and Martin } \\
(1951)\end{array}$ & 1948 & 406 & $12-14$ & $13 \cdot 8$ & $21 \cdot 7$ & $5 \cdot 37$ & $\begin{array}{l}\text { East Indian and } \\
\text { Negro children }\end{array}$ \\
\hline British Guiana & $\begin{array}{l}\text { King and Martin } \\
\text { (1951) }\end{array}$ & 1948 & 100 & $12-14$ & $13 \cdot 0$ & $18 \cdot 4$ & $4 \cdot 91$ & $\begin{array}{l}\text { East Indian and } \\
\text { Negro children }\end{array}$ \\
\hline $\begin{array}{l}\text { South Shields, } \\
\text { England }\end{array}$ & Weaver (1950) & $\begin{array}{l}1943 \\
1949\end{array}$ & $\begin{array}{l}500 \\
500\end{array}$ & $\begin{array}{l}12 \\
12\end{array}$ & $\begin{array}{l}25 \cdot 8 \\
50 \cdot 6\end{array}$ & - & $\begin{array}{l}2 \cdot 4 \\
1 \cdot 3\end{array}$ & $\left\{\begin{array}{l}1.4 \text { p.p.m. fluorine } \\
\text { in water supply }\end{array}\right.$ \\
\hline $\begin{array}{l}\text { North Sheilds, } \\
\text { England }\end{array}$ & Weaver (1950) & $\begin{array}{l}1943 \\
1949\end{array}$ & $\begin{array}{l}500 \\
500\end{array}$ & $\begin{array}{l}12 \\
12\end{array}$ & $\begin{array}{r}4 \cdot 8 \\
26 \cdot 4\end{array}$ & - & $\begin{array}{l}4 \cdot 3 \\
2 \cdot 4\end{array}$ & $\left\{\begin{array}{l}\text { Negligible } \\
\text { fluorine }\end{array}\right.$ \\
\hline Lucknow, India & $\begin{array}{l}\text { Mellanby, M. and } \\
\text { Shah (unpublished } \\
\text { work) }\end{array}$ & 1951 & 266 & 14 & $65 \cdot 8$ & $2 \cdot 71$ & 0.95 & $\begin{array}{l}\text { Pupils from colleges } \\
\text { academies and } \\
\text { schools }\end{array}$ \\
\hline New Zealand & Fulton (1951) & 1950 & 452 & 14 & 0.5 & - & $10 \cdot 01$ & $\begin{array}{l}\text { Urban and rural } \\
\text { samples from State } \\
\text { schooks }\end{array}$ \\
\hline
\end{tabular}

- D.M.F.=decayed, missing, filled. 
TABLE 3

Surface Structure of Children's Teeth in Newfoundland

\begin{tabular}{|c|c|c|c|c|c|c|c|c|c|c|}
\hline & & & \multicolumn{2}{|c|}{ Total No. of Teeth } & \multirow[b]{2}{*}{$\underset{(\%)}{\text { M-Hy॰* }}$} & \multirow[b]{2}{*}{$\underset{(\%)}{M-H y_{1}}$} & \multirow[b]{2}{*}{$\underset{(\%)}{M-H y_{2}}$} & \multirow[b]{2}{*}{$\underset{1 \%}{\mathrm{M}-\mathrm{Hy}}$} & \multirow[b]{2}{*}{$\begin{array}{c}\text { Gross } \\
\text { Hypoplasia } \\
(\%)\end{array}$} & \multirow{2}{*}{$\begin{array}{c}\text { Average } \\
\text { Hypoplasia } \\
\text { Figure } \\
(\%)\end{array}$} \\
\hline & & & $\begin{array}{l}\text { Including } \\
\text { Gross and } \\
\text { Unclassified }\end{array}$ & $\begin{array}{l}\text { Excluding } \\
\text { Gross and } \\
\text { Unclassified }\end{array}$ & & & & & & \\
\hline $\begin{array}{l}\text { Dociduous teeth o } \\
\text { old group } \\
\text { Upper jaw } \\
\text { Lower jaw }\end{array}$ & $\begin{array}{l}5-\mathrm{ye} \\
\ldots \\
\cdots\end{array}$ & $\because$ & $\begin{array}{l}7,078 \\
6,825\end{array}$ & $\begin{array}{l}7,061 \\
6,801\end{array}$ & $\begin{array}{l}17 \cdot 5 \\
38 \cdot 5\end{array}$ & $\begin{array}{l}42 \cdot 5 \\
38 \cdot 5\end{array}$ & $\begin{array}{l}36 \cdot 2 \\
21 \cdot 5\end{array}$ & $\begin{array}{l}3 \cdot 6 \\
1 \cdot 2\end{array}$ & $\begin{array}{l}0 \cdot 2 \\
0 \cdot 2\end{array}$ & $\begin{array}{l}1 \cdot 26 \\
0 \cdot 85\end{array}$ \\
\hline Total & $\ldots$ & $\ldots$ & 13,903 & 13,862 & $27 \cdot 8$ & $40 \cdot 5$ & $29 \cdot 0$ & $2 \cdot 4$ & $0 \cdot 2$ & 1.06 \\
\hline $\begin{array}{l}\text { Permanent teeth } \\
\text { year-old group } \\
\text { Upper jaw } \\
\text { Lower jaw }\end{array}$ & $\begin{array}{l}\text { of } \\
\ldots \\
\cdots\end{array}$ & $\begin{array}{ll} \\
\cdots\end{array}$ & $\begin{array}{l}6,516 \\
7,098\end{array}$ & $\begin{array}{l}6,391 \\
6,918\end{array}$ & $\begin{array}{r}4 \cdot 9 \\
12 \cdot 4\end{array}$ & $\begin{array}{l}30 \cdot 4 \\
47 \cdot 8\end{array}$ & $\begin{array}{l}50 \cdot 4 \\
35 \cdot 9\end{array}$ & $\begin{array}{l}2 \cdot 5 \\
1 \cdot 4\end{array}$ & $\begin{array}{l}1 \cdot 8 \\
2 \cdot 5\end{array}$ & $\begin{array}{l}1 \cdot 51 \\
1 \cdot 26\end{array}$ \\
\hline Total & $\ldots$ & $\ldots$ & 13,614 & 13,309 & $8 \cdot 7$ & $44 \cdot 3$ & $42 \cdot 9$ & $1 \cdot 9$ & $2 \cdot 2$ & $1 \cdot 38$ \\
\hline
\end{tabular}

* $M-\mathrm{Hy}_{0}=$ smooth surface; $M-\mathrm{Hy}_{1}=$ slightly rough; $M-\mathrm{Hy}_{2}=$ definitely rough; $M-\mathrm{Hy}_{3}=$ very rough.

were available, contained 1.5 p.p.m. of fluorine, and this well was also used by a number of families.

Seventeen 5-year-olds who had been born and reared in the district were examined, this number representing more than half the available children in the age-group; 12 of these were caries-free, the percentage of carious teeth over all being only $6 \cdot 2$, as against $38.5 \%$ for the rest of the Island, and the average caries figure $0 \cdot 12$, as compared with $\mathbf{0} \cdot 82$. Comparative figures for 5-year-olds in other areas of endemic fluorosis are given as $11 \%$ of teeth carious. The average caries figure is $\mathbf{0 . 2 1}$ in Maldon and district, England (Coumoulos, 1949), and $2.8 \%$ of teeth carious in 5-year-olds living in a New Jersey fluoride area (Klein, 1948). The caries experience of the St. Lawrence children is therefore of a similar order to that observed for the same age group in other fluorosis areas.

Of the older age group, only four life residents aged 14 could be found, so that an examination was next undertaken of all ages between 6 and 17 . A total of 53 individuals aged 5 to 17 years of age were inspected. Since the numbers in separate age groups were small the general results are given in Table 4, divided up into deciduous and permanent teeth.

Only $9 \%$ of all deciduous teeth were carious, although some of the children were 8,9 and 10

TARe 4

Cartes and Structure in 53 St. Lawrence ChILdRen Aged 5 to 17 LNING in AN AREA Of ENDEMTC Fluoross

\begin{tabular}{|c|c|c|c|c|c|}
\hline & $\begin{array}{l}\text { No. of } \\
\text { Teeth } \\
\text { Examined } \\
\text { for Caries }\end{array}$ & $\begin{array}{c}\text { Per- } \\
\text { centage } \\
\text { Carious }\end{array}$ & A.C.F. & $\begin{array}{c}\text { No. of } \\
\text { Teeth } \\
\text { Examined } \\
\text { for } \\
\text { Structure }\end{array}$ & A.H.F. \\
\hline $\begin{array}{l}\text { Dociduous } \\
\text { Permanent }\end{array}$ & $\begin{array}{l}670 \\
472\end{array}$ & $\begin{array}{l}9 \cdot 0 \\
8 \cdot 7\end{array}$ & $\begin{array}{l}0 \cdot 19 \\
0 \cdot 17\end{array}$ & $\begin{array}{l}634 \\
408\end{array}$ & $\begin{array}{l}0.88 \\
1.49\end{array}$ \\
\hline
\end{tabular}

years of age. The average hypoplasia figure of 0.88 was also low, especially when it is realized that these children had a higher proportion of deciduous molars present than the 5-year group, (deciduous molars being on the average rougher on the external surface than incisors or canines).

Other workers, using the same standards for M-hypoplasia (King, 1944; Coumoulos, 1949), have reported that deciduous teeth in the Maldon fluorosis area of England tend to be of smooth external structure; thus they correlate the low incidence of dental decay with the prevalence of well-formed teeth.

Among the permanent teeth some $8.7 \%$ were found to be carious, with the low average caries figure of $0 \cdot 17$. It is not possible to compare this with the $30.7 \%$ of carious permanent teeth in the 14-year-old group for the rest of the Island, since many of the total number of permanent teeth from St. Lawrence came from children aged 7 to 13 years, and there was an undue proportion of incisors and newly-erupted premolars among their number. The high average hypoplasia figure in the permanent teeth is explained by the frequent presence of mottled 'pitting', giving a rough external feeling to the probe. No fluorine analyses were available for the wells, other than the one supplying the mine, but in view of the low calcium intake, it is probable that 1.5 p.p.m. would be sufficient to cause a disfiguring grade of mottling in some individuals (Murray and Wilson, 1948).

The mode of life and the types of food eaten in St. Lawrence appeared to be very similar to that of other outports on the Burin Peninsula, except that better wages were earned, and this would tend to allow of a greater variety of foods, especially imported tinned products. The standard of living was then coming more into line with that enjoyed in the paper-mill towns, but in those latter, it 
TARE 5

Caries in Newfoundland Childenen aged 2 to 5 years

\begin{tabular}{cccc}
\hline Age & $\begin{array}{c}\text { No. } \\
\text { Examined }\end{array}$ & $\begin{array}{c}\text { Percentage of } \\
\text { Children with Caries }\end{array}$ & $\begin{array}{c}\text { Percentage of } \\
\text { Teeth Carious }\end{array}$ \\
\cline { 1 - 3 } 2 & 4 & None & None \\
3 & 32 & $75 \cdot 0$ & $20 \cdot 6$ \\
4 & 15 & $86 \cdot 7$ & $37 \cdot 0$ \\
5 & 804 & $92 \cdot 8$ & $38 \cdot 5$ \\
\hline
\end{tabular}

cannot be said to have decreased the dental caries (see Tables 1 and 2).

Caries in 2- to 4year Age Groups. It was originally hoped that it would be possible to examine a reasonable number of pre-school-age children between 2 and 4 years, but this proved difficult to organize and was only done on a very limited scale in two localities, St. Johns and Fortune Bay (on the south-west coast). In all 51 were seen, 35 in St. Johns and 16 in south-coast outports. Even in these tiny children there were many with much decay in their teeth, and it will be seen (Table 5) that the proportion of children having decay rises sharply after the age of 2 years, as also does the percentage of decayed teeth.

Gingivitis, Cheilosis and Other Signs Suggestive of Nutritional Deficiencies. Gingivitis of the nonulcerative type in man is regarded by many authorities as due to nutritional defects, but local factors such as tartar deposition, which in turn appears to be influenced by the physical properties of the food eaten, also play a part (King and Glover, 1945). In animals (dogs, rats), which have been maintained post-developmentally on diets adequate in other respects but low in vitamin $A$, the gum epithelium becomes abnormal in that it shows increased keratinization and a tendency for downgrowths to occur below the enamel cement junction (Mellanby, M., $1930 a$ and $b$; 1939; King, 1936). Animals reared on a similar diet, or whose maternal parent was given the deficient diet before their birth, show the same changes much earlier (Mellanby, M., 1930a; 1939; Mellanby, H., 1939; 1941.) Deficiency of this vitamin in childhood might be expected to predispose a population to parodontal disease and it is more than likely that this state of affairs did exist in Newfoundland before the margarine of the islanders' diet was fortified with vitamin A in 1945. It is well recognized that scurvy in man is typically accompanied by gum changes, while swelling and hyperaemia of the gingivae have been produced experimentally in human volunteers as the result of ascorbic acid deprivation (Linghorne et al.,"

- Linghorne, W. J., McIntosh, W. G., Tice, J. W., Tisdall, F. F., McCreary, J. F., Drake, T. G. H., Greaves, A. V. and Johnstone, W. M.
TABu 6

Assocantion between Tartar Deposts aNd OCcurafence of GiNGIVITS IN 5- AND 14-YeAR-OLD GrottPS

\begin{tabular}{|c|c|c|c|c|c|c|}
\hline \multirow[t]{2}{*}{$\begin{array}{c}\text { Grade of } \\
\text { Tartar }\end{array}$} & \multicolumn{2}{|c|}{$\begin{array}{l}\text { Number of } \\
\text { Children }\end{array}$} & \multicolumn{2}{|c|}{$\begin{array}{l}\text { Percentage of } \\
\text { Children with } \\
\text { Gingivitis }\end{array}$} & \multicolumn{2}{|c|}{$\begin{array}{l}\text { Average } \\
\text { Gingivitis } \\
\text { Figure }\end{array}$} \\
\hline & $\begin{array}{l}\text { 5-year } \\
\text { Group }\end{array}$ & $\begin{array}{l}\text { 14-year } \\
\text { Group }\end{array}$ & $\begin{array}{l}\text { 5-year } \\
\text { Group }\end{array}$ & $\begin{array}{l}\text { 14-year } \\
\text { Group }\end{array}$ & $\begin{array}{l}\text { 5-year } \\
\text { Group }\end{array}$ & $\begin{array}{l}\text { 14-year } \\
\text { Group }\end{array}$ \\
\hline $\begin{array}{c}0 \\
\text { (none } \\
\text { visible) }\end{array}$ & 593 & 88 & $30 \cdot 7$ & 73.9 & 0.46 & $1 \cdot 14$ \\
\hline $\begin{array}{c}1 \\
\text { (slight) }\end{array}$ & 104 & 113 & $44 \cdot 2$ & $68 \cdot 1$ & 0.61 & $1 \cdot 21$ \\
\hline$\frac{2}{\text { (moderate) }}$ & 71 & 274 & $59 \cdot 2$ & $79 \cdot 2$ & 0.93 & 1.43 \\
\hline $\begin{array}{c}3 \\
\text { (extensive) }\end{array}$ & 16 & 120 & $(50 \cdot 0)$ & $92 \cdot 5$ & $(0.63)$ & 2.08 \\
\hline Totals & 784* & 595 & $35 \cdot 5$ & 79.0 & 0.53 & 1.47 \\
\hline
\end{tabular}

- A few of the 5-year-old charts could not be used for this Table as either the tartar or gingivitis assessment was in doubt.

1946). All the scientists who have carried out nutritional investigations in Newfoundland agree that the vitamin $C$ intake has been and still is low, more especially in the spring. (McDevitt et al., 1942; 1944; Adamson et al., 1945; Metcoff et al., 1945; Cuthbertson, 1947; Scobie, Burke and Stuart, 1949; Aykroyd et al., 1949; Goldsmith, Darby, Steinkamp, Beam and McDevitt, 1950). In addition to the low vitamin $C$ intake, which until recently was also accompanied by a low vitamin A content of the diet, there little oral hygiene is practised, except by those in the larger centres of population, and the food eaten is for the most part in an overcooked state, so that it is unlikely to have any particular cleansing properties. It seems from the foregoing remarks that gingival disease might be expected to be common among the inhabitants of the island, and this has been recorded by several observers as occurring among all ages of the population, but particularly among young adults, especially the women. On the basis of the rough classification referred to on page 275, $35.5 \%$ of the 5 -year-olds and $78 \%$ of the 14 -yearolds had some degree of gingival abnormality, the respective average gingivitis figures per child being 0.53 and 1.47: There was a definite variation in the incidence in different localities, the Burin Peninsula and south-west coast children having once again the highest number of individuals affected (Table 7). Aykroyd et al. (1949), in a sample of the population aged 0-89 years, report an increased incidence of gingivitis in 1948 over their 1944 survey, and conclude from this that the average vitamin $C$ intake is still much below the optimum.

The 5-year-old group did not show an unduly high gingivitis incidence when compared with 
TARE 7

Incidence of Grgantits, Chellosis and Other Condmons Suggestive of Nutrmonal Deficienctes in 5- ANd 14-Year-AGe Groups

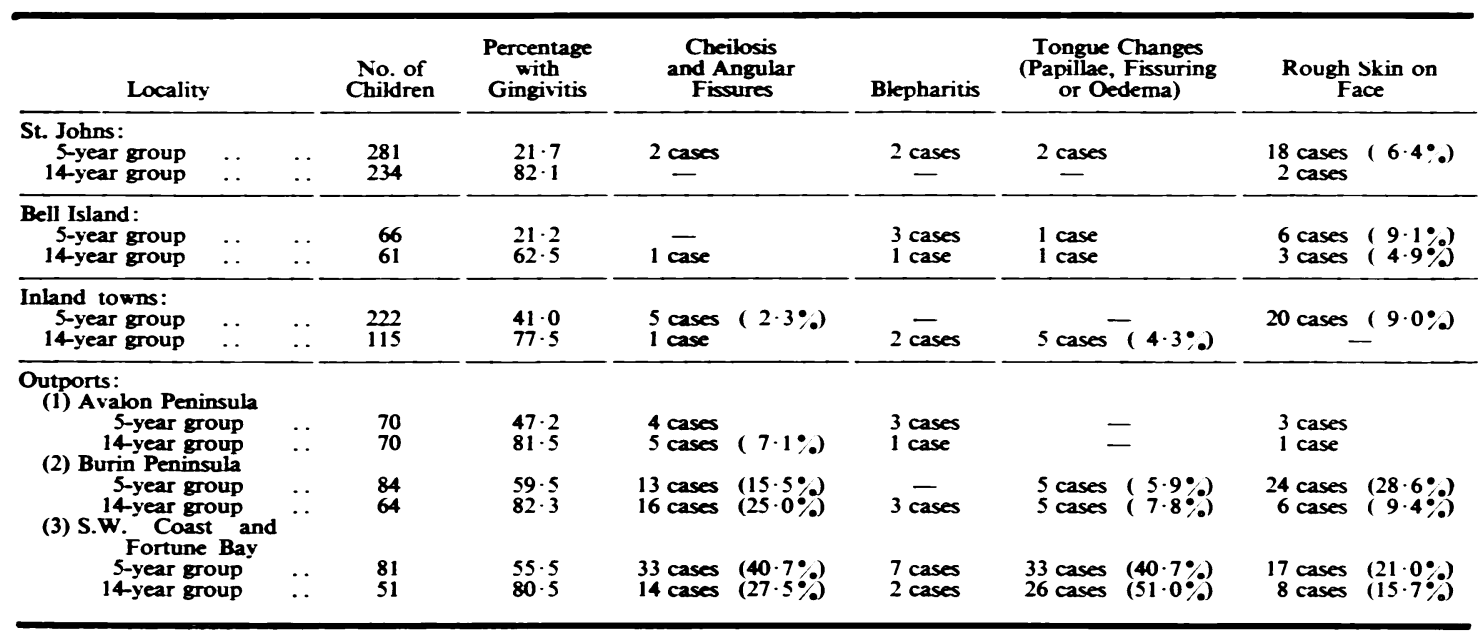

London children of the same age, who in 1947 had $49 \%$ of individuals affected (Mellanby and Mellanby, unpublished work). It is probable that in Newfoundland the underlying developmental predisposition would affect the older age groups to a greater extent, since those children aged 5 in 1948 (the date of this survey) should have been getting more vitamin $\mathbf{A}$ at a critical time in the development of the gingivae than either the older children or adults had received.

The 14-year-old group showed a slightly greater incidence and extent of gingivitis than did London school children of the same age in 1947 (Mellanby and Mellanby, 1952) when $74 \%$ of the individuals were affected and the average gingivitis figure per child was 1-26. King (1940) found a very high incidence of this condition $(96 \cdot 2 \%)$ among 13-15-year-old children living in rural crofting communities in the Isle of Lewis, Scotland. In the West Indies he found the incidence less, $83-89 \%$ (King and Martin, 1951), though here he was employing a more refined classification.

The association between the occurrence and extent of visible tartar deposits and gingivitis is given for both the Newfoundland age groups in Table 5. In the deciduous teeth tartar was nearly always confined to the upper first and second molars. In the permanent dentition the lower incisor region was also frequently involved. Each child was placed in one of four tartar groups, $0,1,2$ or 3 , according to the area covered on the buccal surface of the upper molars (deciduous and permanent) or the area on the lingual surface of the lower incisor region. It was found that the incidence and extent of gingivitis increased con- siderably between the children graded tartar-free and those with grade 3 tartar.

Table 7 gives the incidence of cheilosis, blepharitis, tongue changes and roughened skin on the face in the two age groups of 5 and 14 years from the different localities. From this it will be seen that cheilosis and tongue changes were much more frequently observed in the outports of the Burin Peninsula and the Fortune Bay area than elsewhere. Rough skin on the face also tended to be higher in these places, but it was not uncommon even in the inland towns. It was found by Aykroyd et al. (1949) and Goldsmith et al. (1950) that most of the characteristic signs of malnutrition were less conspicuous and less prevalent in 1948 than in 1944. This they attributed to the several successive attempts on the part of the Government to improve the nutritional situation. The first of these was the enriching of all flour with thiamine, riboflavine, niacine and iron after July, 1944. Since September, 1945, the margarine sold has all been fortified with vitamin A to a level of 45 I.U. per gram, while in November, 1947, the flour was additionally fortified with $0.5 \%$ bone meal. Apart from these general measures the special free provision of a hot cocoa-milk powder drink for school children was begun in 1947. Cod liver oil was also made available to schools during the winter months, and concentrated orange juice was provided for expectant mothers and young infants. A propaganda campaign was started to encourage mothers to take up these special foods for themselves and their children, and this has been combined with efforts to improve the local methods of cooking and to encourage the growing of more vegetables. 
Diet in Newfoundland

Reference has already been made at the beginning of this paper to the restricted diet available to the average Newfoundlander, especially those living in small settlements. Cuthbertson (1947) gave a detailed report of the situation as he found it two years before this survey was made, and I was able to confirm many of his findings from personal observation. He stated that in the outports the basic diet consisted of fish, white flour $(\mathbf{7 0} \%$ extraction), molasses or sugar, margarine and tea, to which were added home-grown cabbages, turnips and potatoes. A little tinned milk, and other imported luxuries were also consumed, but the amount of these depended on the success or failure of the fishing season. Fresh meat was often difficult to obtain, so that fish, frequently salted or dried (almost exclusively the white flesh of cod), and salt pork were the chief sources of animal protein. Wild fruits were stored for winter use, and with potatoes provided the only source of vitamin $\mathbf{C}$ for seven or eight months of each year. Families with some livestock did better, but even in their case, climatic conditions and indifferent animal husbandry left them without milk or eggs for many months of the year. The net result was a diet which might have been adequate in calories, but which was very low in all protective foods and calcium. The total carbohydrate intake was above that of neighbouring countries, being $67 \%$ as compared with $51 \%$ in the U.S.A. and Canada. The phosphorus was high, due to the preponderance of fish and white flour, which probably aggravated the calcium shortage. The intake of the vitamin B complex was also low until the enrichment of the flour in 1945, especially in view of the high carbohydrate consumption. Before the margarine was reinforced with vitamin A it is probable that the intake of this essential food factor was well below the minimum. Eye changes due to its lack were reported as being previously fairly common (Adamson et al., 1945). On such a diet it might be expected that the vulnerable section of the population, the young children and pregnant women, would fare worst.

The work of May Mellanby has shown that the macroscopic and microscopic structure of teeth in several species of animals can be profoundly altered by dietary means during the period of development (Mellanby, 1918, 1920, 1923b, 1928). In children's teeth she has shown that very many deciduous teeth do have minor defects (1923a, 1927, 1929) which have been termed degrees of M-hypoplasia by King (1940). Such defects are similar to those found in animals reared on experimental diets and are therefore thought to be due to deficiencies in our ' civilized' types of food. May Mellanby and her colleagues have also shown in numerous surveys that children's deciduous teeth with M-hypoplasia are more liable to decay than those of smooth surface texture. On the basis of her animal experiments, the type of diet likely to produce smooth-surfaced teeth in children would be one in which liberal amounts of milk and fatsoluble vitamins were included. She has also shown that teeth may be influenced by this type of diet after eruption in such a way as to arrest decay already present and postpone the development of new caries (Mellanby, 1928; Mellanby and Pattison, 1926; Mellanby, Pattison and Proud, 1924).

If more milk, eggs, fruit, fresh vegetables and regular cod liver oil were to be included in the diets of Newfoundland mothers and of children, especially those under 5 years, this might be expected to reduce the amount of M-hypoplasia and of caries in Newfoundland children.

The Government is trying to encourage the consumption of milk among school children by popularizing the drink of 'cocoa milk' which would give each child the calcium equivalent of one-third of a pint of milk on school days. Cod liver oil is distributed to school children and both it and orange juice are available to children under 5 , but the uptake could be much increased. The extra calcium in the bread should help to rectify the low level of this mineral in the average diet.

The Island has done very much better economically since the last war, and in many places there is now well-paid work available as an alternative to fishing; family allowances introduced since the union with Canada should also do much to alleviate the poverty among the many large families. The improvement in the economic situation, however, must be backed up by extensive dietary propaganda if it is to succeed in giving children the type of food they need. All too often higher wages only mean more sweets and soft drinks for the children, instead of more milk and protective foods.

\section{Summary}

The results of this survey are based on the examination of 1,486 children, the majority of whom were aged $5(804)$ or 14 years (595).

Dental caries was widespread in all localities with the exception of one small area of endemic fluorosis, only $7 \cdot 2 \%$ of the 5-year-old children and under $1 \%$ of the 14-year-group being free from caries. The total percentage of deciduous teeth decayed was 38.5, while among the permanent teeth of the 14-year-group, $30.7 \%$ were already carious. This corresponds to a decayed-missing-filled 
rate per child of $7 \cdot 4$ for deciduous teeth, and of 8.39 for the permanent ones.

Both the deciduous and permanent teeth were found to be of relatively poor structure, only $27.0 \%$ of the former and $8.7 \%$ of the latter having no M-type hypoplasia.

The percentage incidence of gingivitis, cheilosis, angular fissures, tongue changes and blepharitis were recorded.

The dietetic factors which may have been responsible, at least in part, for this state of affairs, are discussed.

In conclusion I wish to express my thanks to all those who assisted me with the preparatory work of the survey, and in particular to Lady (May) Mellanby for her generous help and encouragement. I am indebted to the Honourable W. H. Quinton, Commissioner of Public Health and Welfare, Newfoundland, for extending to me the facilities of his department. The success of the survey depended to a large extent on the careful plans laid by the Deputy Minister of Health, Dr. Leonard A. Miller, and the Assistant Deputy Minister of Health, Dr. James McGrath, in co-operation with the Department of Education. I was most fortunate to have Miss Ella Brett, B.Sc., Nutritional Adviser to the Department of Public Health and Welfare, Newfoundland, and Nurse Margaret Hall as my personal assistants while carrying out the examinations of the children. The expense of the investigation was met by the Medical Research Council of Great Britain and the Newfoundland Government.

Breuogenphy

Adamson, J. D., Jolliffe, N., Kruse, H. D., Lowry, O. H., Moore, P. E., Platt, B. S., Sebrell, W. H. Tice, J. W.. Tisdaill, F. F., wilder, R. M. and Zamecnik, P. C. (1945). Canad. med. Ass. J., $52,227$.

Appleton, V. B. (1921). Amer. J. publ. Hlth., 11, 617.

\begin{tabular}{l} 
Appleton, W. B. (1930). J. Hyg., Land, 33, 357. \\
Aykroyd, \\
\hline
\end{tabular} R. E., Tisdall, F. F., Wilde, R. M. and Zamecnil, P. C. (1949). Canad. med. Ass. J., CO, 329.
Coumoulos, H. (1949). Brit. dent. J., 86, 172.

Cuthbertson, D. P. (1947). "Report on Nutrition in Newfoundland' Dominions Office No. 4. H.M. Stationery Office, London.

Dean, H. T., Jay, P., Arnold, F. A. and Elvove, E. (1941). Publ. Hith. Rep., Wash., 56, 761.

Futton, J. T. (1951). Bull. Wld. Hlth. Org., 4, 1.

Goldsmith, G. A., Darby, W. J., Steinkamp, R. C., Beam, A. S. and McDevitt, E. (1950). J. Nutr., 40, 41.

Kine. J. D. (1936). J. Physiol., Lond. 88, 62.

King. (1940). Spec. Rep. Ser. med. Res. Coun., Land., No. 241.

二-(1940). Spec. Rep. Ser. med.

and Glover, R. E (1945). J. Path. Bact., 57, 353.

and Martin, W. J. (1951). Brit. dent. J., 90, 35 and 63.

Klein, H. (1948). Publ. Hlth. Rep., Wash., 63, 563.

— and Palmer, C. E. (1937). Publ. Hlth. Buil., Wash., No. 239. 75 and Knutson, J. W. (1938). Publ. Hlih. Rep., Wash., 53. 751.

Knutson, J. W., Klein, H. and Palmer, C. E. (1940). J. Amer. dent. Ass., 27, 579.

Linghorne, W. J., McIntosh. W. G., Tice, J. W., Tisdall, F. F., MCCreary, J. F., Drake, T. G. H., Greaves, A. V. and Johnstone W. M. (1946). Canod med. Ass. J., 54, 106.

Little, J. M. (1912). J. Amer. med. Ass., 58, 2029.

McDevitt, E., Dove, M. A., Dove, R. F. and Wright, I. S. (1942). Proc. Soc. exp. Biol., N.Y., 51, 289.

Melhaby, H. (1939) (1944). Ann. intern. Med., 20, 1

J., 66, 76.

(1941). J. dent. Res., 20. 489.

(1949). Brit. dent. J., 87, 321

and Mellanby, M. (1950). Brit. med. J., 1, 1341.

Mellanby, M. (1918). Lancet, $2,767$.

- (1920). Dent. Rec., 40, 63.

- (1923a). Brit. dent. J., M4, 1 .

- (1923b). Ibid., M4, 1031

- (1927). Ibid., 48, 1481.

- (1928). Physiol. Rev. \& 545

- (1929). Edinb. med. J., 36, (Trans. Edinb. obstet. Soc., 88, 25.)

- (1930a). Proc. roy. Soc. Med., 23, 1503.

- (1930b). Spec. Rep. Ser. med. Res. Covan., Lond. No. 153.

- (1939). Dent. Rec., 59, 227.

- and Coumoulos, H. (1944). Brit. med. J., 1, 837.

(1946). Ibid. $2,565$.

and Mellanby, H. (1948). Ibid., 2, 409.

(1951). Ibid., 1, 51.

二- (1951). Ibid., 1, 51.

- and Pattison, C. L. (1926). Brit. dent. J., 47, 1045.

and Proud, J. W. (1924). Brit. med. J., 2354

and Shah, M. A. Unpublished work.

Metcoff, J. Goldsmith, G. A. Mcoveeney, A. J., Dove, R. F. McDevitt, E., Dove, M. A. and Stare, F. J. (1945). J. Lab. clin. Med., 30, 475.

Murray, M. M. and Wilson, D. C. (1948). Brit. dent. J., $84,97$.

Schour, I. and Masseer, M. (1947). J. Amer. dent. Ass., 35, 1 .

Scobie, K., Burke, B. S. and Stuart, H. C. (1949). Canad. med. Ass. J., 6., 233.

Sydenstricker, V. P. (1941a). Amn. intern. Med., 14, 1499.

(1941b). Ibid., 15, 45 .

Toverud, G. (1949). J. Amer. dent. Ass., 39, 127.

Weaver, R. (1950). Brit. dent. J., \&, 231. 